Erratum

\title{
Erratum: Li, C.P.; Duan, L.C.; Tan, S.C., et al. Influences on High-Voltage Electro Pulse Boring in Granite. Energies 2018, 11, 2461
}

\author{
Changping Li ${ }^{1,2}$, Longchen Duan ${ }^{3, *}$, Songcheng Tan ${ }^{3}$ and Victor Chikhotkin ${ }^{3}$ \\ 1 School of Automation, China University of Geosciences, Wuhan 430074, China; lichangpingcug@126.com \\ 2 School of Mechanical Engineering and Electronic Information, China University of Geosciences, \\ Wuhan 430074, China \\ 3 Faculty of Engineering, China University of Geosciences, Wuhan 430074, China; \\ wstansongcheng@163.com (S.T.); vch56@mail.ru (V.C.) \\ * Correspondence: duanlongchen@163.com; Tel.: +1-388-608-1092
}

Received: 14 May 2019; Accepted: 15 May 2019; Published: 16 May 2019

The authors wish to make the following corrections to this paper [1]: the order of the first and second affiliations would be changed. The School of Automation in China University of Geosciences (Wuhan) would be made the first affiliation.

We would like to change the first and second affiliations on page 1 of the paper [1] from:

1 School of Mechanical Engineering and Electronic Information, China University of Geosciences, Wuhan 430074, China

2 School of Automation, China University of Geosciences, Wuhan 430074, China; lichangpingcug@126.com

to the correct version, as follows:

1 School of Automation, China University of Geosciences, Wuhan 430074, China; lichangpingcug@126.com

2 School of Mechanical Engineering and Electronic Information, China University of Geosciences, Wuhan 430074, China

The authors would like to apologize for any inconvenience caused to the readers by these changes.

\section{Reference}

1. Li, C.P.; Duan, L.C.; Tan, S.C.; Chiktoykin, V. Influences on High-Voltage Electro Pulse Boring in Granite. Energies 2018, 11, 2461. [CrossRef]

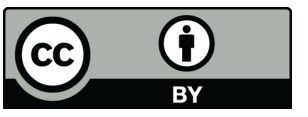

(C) 2019 by the authors. Licensee MDPI, Basel, Switzerland. This article is an open access article distributed under the terms and conditions of the Creative Commons Attribution (CC BY) license (http://creativecommons.org/licenses/by/4.0/). 